УДК 811.161.2’373.2

І.М. Демешко

\title{
АНТРОПОНІМІКОН У ПОЕЗІЇ Є. МАЛАНЮКА: СЕМАНТИКО-СТИЛІСТИЧНИЙ АСПЕКТ
}

Розгляд літературного твору з позицій будь-якої науки передбачає врахування діалектичної єдності змісту й форми. Автор має можливість втілити свою думку посередництвом певних мовних засобів. Кожна складова частина тексту є носієм ідейного змісту. Вивчення антропонімікону узгоджується із системністю як основною рисою художнього твору. Різноманітність іменувань дає змогу письменнику повно та виразно розкрити художні образи та точніше їх охарактеризувати, створює особливий колорит та неповторний авторський стиль. Антропоніми в художньому творі виконують інформативну, експресивну, текстотвірну, номінативну, соціологічну, локативну, характеризувальну, експресивно-оцінну функції і беруть участь у створенні образів у тексті. Асоціація - один із найпоширеніших засобів формування семантики власних назв у тканині тексту. Актуальність дослідження зумовлена відсутністю в українському мовознавстві системного аналізу антропонімної парадигми С. Маланюка, потребою комплексного вивчення структурної та семантичної специфіки використаних автором антропонімів.

Дослідження з літературної ономастики завжди привертали увагу лінгвістів. Теоретичні основи сучасної лінгвостилістики представлені в працях Ю. О. Карпенка, В. М. Калінкіна, В. Д. Бондалетова, С. С. Отіна. Вивченням ономастики творів української літератури займалися Г. П. Лукаш, М. Р. Мельник та ін., але й донині залишається актуальним дослідження функційно-стилістичних особливостей антропонімів у художньому творі. О. О. Семенець зазначає, що державницька історіософська концепція - непохитне творче кредо С. Маланюка - детермінує сам принцип побудови образної системи його поезій, становить основу художньо-образного освоєння дійсності [8, с. 67]. Суть цієї 
концепції й роль поетонімів у їі розкритті та безпосередній реалізації простежимо на аналізі окремих збірок та віршів поета.

Мета статті - дослідити функційно-стилістичні особливості антропонімів у поезії С. Маланюка, описати їх роль у вираженні основної ідеї. Досягнення поставленої мети передбачає розв'язання таких завдань: 1) описати специфіку використання антропонімів у поезії Є. Маланюка; установити їх контекстуальну й текстотвірну сутність; 2) розкрити функційно-стилістичне навантаження антропонімів, використаних у творах та проаналізувати ситуації вживання моделей на тлі епохи й жанру; 3) дослідити вплив оніма на сприйняття образів читачем та визначити особливості ідіолекту поета крізь призму власних імен; 4) з'ясувати особливості побудови антропонімного простору та літературних антропонімів у системі художнього тексту.

Матеріалом дослідження слугували антропоніми Є. Маланюка, дібрані шляхом загальної вибірки з поетичних творів письменника. Методи дослідження зумовлені специфікою онімного матеріалу, який потребує комплексного підходу й описового методу, що уможливлює аналіз антропонімного макрополя поетичних творів С. Маланюка. Для вивчення структури та змісту цих онімів використано відповідно словотвірний і семантичний аналіз.

Антропоніми, як й інші типи власних назв у творі, формують $\mathrm{i}$ представляють у сукупності власний простір у літературно-художньому творі. Добір антропонімів для письменника - це прояв його літературної індивідуальності та художньої майстерності на тлі реальної суспільно-історичної дійсності. На думку В. М. Калінкіна, критеріями цього добору виступають: 1) відповідність використаних антропонімів художнім завданням, що розв'язуються у творі; 2) взаємовплив літературного тексту на оніми і навпаки; 3) ономастична компетенція потенційного читача $[1$, с. 168]. Антропонім у художньому тексті втрачає свої потенційні, реальні можливості власної назви, які реалізувались у мові й мовленні, і здобуває якості літературного оніма (поетоніма) позначати не реальні, а існуючі у творчій свідомості автора (передані через текст) у свідомості реципієнтів образи, вигаданих чи реальних об'єктів, названих онімом, зокрема антропонімом. 
У художньому творі діють свої закони й закономірності, письменник не фотографічно відтворює реальність, а відбирає матеріал та естетично освоює його, орієнтуючись на художню мету. Міра й ступінь правдоподібності у творах бувають різними, але вони не впливають на їхню естетичну вартість. На нашу думку, кожна одиниця художнього твору працює на втілення авторської ідеї, тому доречно враховувати іiі ідейне навантаження в загальній структурі використаних письменником засобів.

Значну роль у створенні збірки «Стилет і стилос» відіграли антропоніми. Їх можна умовно розподілити за такими тематичними групами: 1) митці: Т. Шевченко, П. Куліш, М. Коиюбинський, Леся Украӥнка, Гоген (художник), Г. Сковорода (філософ); 2) історичні діячі: Мазепа, Нестор (літописець), Богдан, Гонта, Орлик, Соломон; 3) міфологічні й біблійні персонажі: Сибіла (мандрівна пророчиця), Бог, Перун, Муза, Пітія (жриця), Петроній, Адонай (іудейський бог), Анна (мати Маріі); 4) літературні персонажі: Дон Кіхот, Офелія; 5) сучасники автора: Юрій Дараган, Максим Рильський, Павло Тичина, Наталочка (Лівищька-Холодна), Ганна Редер; 6) авторські антропоніми (новотвори): Ти, Ти Одна (персоніфікація України), Малоросійський Сремія. Уживані антропоніми дозволяють $Є$. Маланюку в максимально ощадливому просторі поетичного тексту розгорнути значний об'єм інформації. Їх використання створює асоціативні зв'язки, що розширюють простір поезії, допомагають письменнику повніше висловити себе та встановити зв'язок з читачем. У «Біографії) $С$. Маланюк використовує художній прийом персоніфікації території України, що проявляється на рівні мовних засобів - уведення в текст займенників - Tu, Ти Одна. Перехід займенника у власну назву підкреслює важливість Батьківщини в житті поета, інтимізує звертання, надає йому відтінку винятковості. Поезія «Пам'яті Куліша» містить ряд антропонімів, проте експресивністю звучання виділяється одиниця - Малоросійський Єремія. Образ біблійного пророка, який був приречений на блукання й нерозуміння проектується на модель українського культурного й історичного простору, на самого автора, якому дісталась роль речника поневоленої нації. Виразно негативного значення набуває в цьому контексті, як і у 
32 Наукові записки ХНПУ ім. Г.С. Сковороди. Літературознавство, 2019, вип. 3(93)

всій подальшій творчості С. Маланюка означення малорос, що містить у собі приниження й безсилля українців - сучасників поета.

Трагічним пафосом і драматизмом позначений ліричний диптих Є. Маланюка «Пам’яті Куліша». Перший вірш «Невже ж надії всі пропащі?..» має присвяту «Малоросам», якою детермінується одна 3 найважливіших ділянок громадської діяльности співця - боротьба за порятування українців від почуття вторинности, від пристосуванства, інертности й відступництва. За низкою риторичних питань відкриваються болісні роздуми просвітника над долею України, перетвореної на глуху російську провінцію, заселену денаціоналізованим елементом - малоросами, чи то хохлами, позбавленими державницького мислення, гідности та гордости [7, с. 4].

Апелювання до імен Т. Шевченка, Г. Сковороди, I. Мазепи, Б. Хмельнищького, П. Орлика у творах є закликами до консолідації енергії державності й активних дій на іï захист. Вірш «Сучасники» вміщує ще один авторський новотвір - антропонім-конструкцію на позначення України - «Божевільна Офелія половещьких степів». Це порівняння підкреслює катастрофічність, пустку нашої землі зі встановленням на iї території більшовицької влади. У вірші «Уривок $з$ поеми» перед читачами постають антропоніми Б. Хмельницький, I. Мазепа, М. Залізняк, I. Гонта. Поет прагне пробудити в читача психологію переможця. Образи українських гетьманів у ліриці Є. Маланюка виступають символами як перемог, так і поразок.

У наступних двох збірках С. Маланюка: «Гербарій» (1926 р. - друк), «Земля й залізо» (1930) окреслені тенденції використання антропонімного матеріалу лише підсилюються. 3'являється протиставлення автора через опозицію Свген (власне ім'я), ініціальної формули $C$. $M$. та поетів, з якими він не міг узгодити власних світоглядних принципів тичини, сосюри (форми множини). Переходом власних імен у загальні митець підкреслив своє осудливе, викличне ставлення до конформістської, пасивної позиції земляків. Уживаються імена B. Стефаника, П. Куліша, М. Кочюбинського, Лесі Українки, Т. Шевченка, які також підсилюють створений поетом ідеологічний контраст. 
Отже, у зазначених збірках антропоніми, використані Є. Маланюком, становлять собою значущі національно-культурні компоненти i водночас виконують художньо-оцінювальну функцію. Емоційно-експресивні варіанти імен є своєрідним засобом імпресії, що дозволяє передати внутрішнє через зовнішнє, психологічний стан поета через антропонім.

Г. І. Мельник зазначає: «майстерно добираючи і використовуючи власні назви, передусім антропоніми, Свген Маланюк у своїй збірці віршів «Земна Мадонна» (1934), як і в інших < . .>, завжди ставить оніми в такий контекст, щоб вони максимально сприяли адекватності художнього твору, тим самим роблячи онімію важливим складником свого ідіостилю» [6, с. 206]. У своїх прозових дослідженнях, зокрема в статті «Малоросійство» [2, с. 219] письменник неодноразово наголошував на ментальній рисі українців - покорі, що поєднується з мовчанням, бездіяльністю, страхом. Тому поряд з Богом у віршах з'являється образ Месії як передвісника здійснення давньої мрії - здобуття Україною незалежності. У цьому ж ряді вживаються оніми: Мойсей, Петро, Пантелеймон, Ангел. Часто вводить у тексти С. Маланюк ім'я Марія, яке в різних поезіях належить Божій Матері; гіпотетичній українці, що народить спасителя Україні; конкретній жінці, незалежно від ії людських якостей, яка просто має таке ім'я [6, с. 210]. У перших двох значеннях поряд $з$ ім'ям Марія вживається «пані Богородиця», Мадонна, іноді 3 малої літери мадонна, що означає Божа Матір, та жінка, що народить українського Месію; сама Україна.

У збірці вживаються такі іншомовні антропоніми: Андромаха, Беатріче, Квазімодо, Мефіст, Фавст, Маргарита, Джоконда. Українських персонажів тільки два - Марко Проклятий (фольклорний образ) та Вій. Образне утворення А. Данте Беатріче тяжіє до алегоричності внутрішньою сутністю. Це Беатріче-Украӥна «польова», $з$ ланами пшениці, а також виступає як уособлення високоморальності української жінки, як авторський мистецький пошук образу ідеальної жінки. Якщо вектор ідеалу флорентійця спрямований до неба, то в С. Маланюка - духовний контакт з Україною. Серед згаданих С. Маланюком історичних осіб переважають такі, як: Клеопатра, Бетховен, Гріг, 
34 Наукові записки ХНПУ ім. Г.С. Сковороди. Літературознавство, 2019, вип. 3(93)

P.-М. Рільке (австрійський поет), Батий, Тімур, Растреллі, Лукреція (давньоримська героїня, завдяки якій було повалено царство етрусків у Римі), маркіза де Ламбаль (фаворитка королеви Марії-Антуанети; потрапила, як і їі господиня, на гільйотину), Д. Чаплинський (відомий як особистий ворог Б. Хмельницького).

Серед українських митців, діячів - T. Шевченко, М. Башкириева, М. Гоголь, криптонім Ю. Л. (Юрій Липа), І. Мазепа, С. Петлюра, П. Полуботок, Богдан (Хмельницький): «І ось - Стефаник і Куліш, Ось - Коцюбинський, Леся - квіти Степів страждальної землі, Народу самосійні діти!» [5, с. 69]. С. Маланюк пишається творчими здобутками краян, що є символами національного оновлення й світової слави України. Безперечно, органічна єдність особистого й національного, історичного в ліриці підносить поета-патріота, борця, емігранта до узагальненої постаті національно усвідомленої генерації українства, що в роки боротьби за волю держави осмислювала історичне буття країни. Автор веде шляхами перемог, нагадує образи Київської Русі, козацької України, Б. Хмельницького, П. Орлика, I. Мазепи («Вітер історії» (1924), «Варязька балада» (1925)).

У маланюковому поетичному світі використовуються назви на позначення митців різних епох - Гомер і Еврипід, Горащій $і$ Петроній, Нестор і Шекспір, Вольтер $і$ Сковорода, Мічкевич і Пушкін, Бодлер і Верлен, Рембо і Рільке... Вірші «Станіслав Виспянський», «Марії Башкирцевій», «Миколі Зерову», «Юрієві Дараганові», «Пам’яті Т. Осьмачки», «Подебрадці», «Волинське», ліричні присвяти Юліянові Tувіму («Ars poetica»), Миколі Гумільову («Пам’яті поета і воїна»), Анні Ахматовій («Антистрофи»), Миколі Хвильовому («Березіль»), «Юрієві Липі («Ю. Л.»), Олександрові Наріжному («Три сонети»), Дмитрові Донцуову («Крик Ксенофонтових фаланг...»), Наталі Лівиџькій-Холодній («Знаю, що сумно вчитись латини...»), Уласові Самчуку («Володимерія»), Олені Телізі («А ще забуду тебе, Ієрусалиме...»), Оксані Лятуринській («Камінь») та ін. допомагають зрозуміти автора, його громадські й мистецькі орієнтири, відчути співзвучність у доробку письменника національних і загальнолюдських проблем [7, с. 6]. У вірші «Сага» постають образи Рюрика, Ольги, Олега - зачинателів Київської 
Русі. Автор, звертаючись до славних сторінок історії українського народу, прагне використати їх як ідеал для досягнення важливої мети державотворення.

Збірка «Земна Мадонна» (1934) - вершина авторських звертаннях до власних імен. «Грецька» й «римська» антропонімні парадигми $€$ наскрізними у творчості поета й засвідчують його концепцію державотворення. Створюючи своєрідні мікротексти, антропоніми допомагають локалізувати зображуване в просторі та часі, надати йому національного забарвлення. Темоутворювальна функція антропонімів забезпечує інформативно-понятійне наповнення тексту. Крім того, антропоніми в поетичних творах $Є$. Маланюка виконують певну стилістичну та художню функції, характеризують мову й стиль автора, стають засобом вираження авторської модальності, спрямованої на створення цілісної історіософської системи та іiї реалізації в конкретно визначеному часі - роки життя самого поета, а згодом, як настанови нащадкам, що поглиблюють художню вартість віршової спадщини письменника. «Назвою збірки «Перстень Полікрата» (1939р.) автор натякає на невідворотність долі ії ліричного героя - українського поета-емігранта, а водночас і на приреченість його вітчизни. Мотив, пов'язаний із коштовним перснем давньогрецького тирана із Самосу, що фатально переслідує Полікрата й доводить до нещастя, органічно вплітається в болючі роздуми Є. Маланюка над лихоліттям України. Звільнитись від тягаря невідворотного занепаду й приреченості рідна земля може лише завдяки новим паросткам» [3, с. 35].

Пронизує твори ідея того, що українська культура пройшла становлення зі своєї давньої належності до античної Еллади. На думку поета, українці успадкували від давніх греків цілий набір рис: людська індивідуальність як чинник світогляду; лагідна душа; мудрість, які фактично виключають наявність войовничості й здатності до агреciï. Неодноразово у творах Україна номінується як Степова Еллада 3 позитивними чи негативними відтінками у вживаннях. Антропонімікон сфери давньогрецької культури включає імена багатьох політичних діячів, філософів, митців: Перикл, Олександр Македонський, Сократ, Геродот, Геракліт, Гомер. Поетичному втіленню авторської 
36 Наукові записки ХНПУ ім. Г.С. Сковороди. Літературознавство, 2019, вип. 3(93)

історіософської концепції слугують також міфоніми: Геракл, Прометей, Аполлон, Афродіта, Кассандра. Використовує поет також переосмислені образи творів Гомера: Одіссей, Каліпсо, Навсікая, Пенелопа. «Еллінська» парадигма образів у творчості С. Маланюка представлена різноманітними класами антропонімів. Культ краси, мрійливість і зажура, успадковані українцями від греків не сприяли, за переконаннями Є. Маланюка, формуванню державності, а навпаки - обеззброювали націю в період державотворення. Рим убачався поетом ідеалом могутньої держави й нації, владної та войовничої. «Римська» парадигма значно вужча, бо сконцентрована на втіленні провідної ідеї міліарного духу й державності. У цьому участь беруть антропоніми на позначення видатних політичних діячів, імператорів, полководців (Цезар, Марк Аврелій); філософів, учених, письменників (Сенека, Архімед, Горацій); легендарних героїв (Муцій); міфологічних персонажів (Mapc) [4, с. 75]. Гармонійне поєднання грецьких та римських рис є авторським ідеалом для української нації.

У наступних збірках автор продовжує діалог з іншими поетами на сторінках своїх творів, висловлює за допомогою антропонімів власне ставлення до мистецтва. Повагу Миколі Зерову (представнику неокласичної школи) Є. Маланюк в однойменній поезії протиставляє іронічно-зниженому ставленню до творів футуриста Валер'яна Полішука, що знаходить втілення на лексичному рівні: «...Декретний друк вже припадає пилом. Крамниці на вагу давно скупили Обгорточний верлібр поліщуків...» [3, с. 214]. Неодноразовим є звертання Є. Маланюка до імені й творчості Й. С. Махара - переспівувача й інтерпретатора багатьох біблійних сюжетів.

Помітна тенденція і до кількісного переважання у творах останніх років таких антропонімів, як Василь Тютюнник, Улас Самчук, Олена Теліга, Микола Хвильовий, Олег Ольжич та ін. Автор прагнув відкритого діалогу з митцями, своїми читачами, далекими історичними епохами й різними культурами. У переважній більшості поезій С. Маланюка використовуються антропоніми, тому складним завданням буде знайти такий твір, у якому б вони були не представлені. Усе це свідчить про пильну увагу поета до свого слова й розуміння його істинної ваги, а 
також про беззаперечний інтелектуалізм як одну з прикметних рис індивідуального авторського почерку.

Шляхом лінгвостилістичного аналізу в цьому дослідженні було розкрито основні функції літературних антропонімів, відібраних з десяти поетичних збірок Є. Маланюка («Стилет і стилос» (1925), «Гербарій» (1926), «Земля й залізо» (1930), «Земна Мадонна» (1934), «Перстень Полікрата» (1939), «Влада» (1951), «Проща» (1954), «Остання весна» (1959), «Серпень» (1964), «Перстень і посох. Епілоги» (1972), а також з віршів поза збірками.

Таким чином, на антропонімному матеріалі охарактеризовано індивідуальні авторські риси творення й використання імен, описано їхню роль у вираженні основної ідеї. Антропоніми репрезентують специфіку твору словесного мистецтва як системи. Системний аналіз творчості митця вимагає розуміння мови як інтегральної науки.

Антропоніми формують і представляють у сукупності власний атропонімний простір у літературно-художньому творі і в усьому творчому доробку митця. Державницька історіософська концепція визначила організацію текстів Є. Маланюка на всіх досліджуваних рівнях. Антропонімікон, використаний письменником, організовується в такі тематичні групи: митці, історичні діячі, міфологічні, біблійні, літературні персонажі, сучасники, авторські антропоніми.

Вибираючи антропонімійну модель іменування, керувався їхньою функційно-стилістичною доцільністю. Досліджені одиниці становлять собою значущі національно-культурні компоненти і водночас виконують художньо-оцінювальну функцію в переважній більшості його текстів. Емоційно-експресивні варіанти імен - своєрідний засіб імпресії, що дозволяє передати внутрішнє через зовнішнє, психологічний стан поета через антропонім. Літературні антропоніми разом 3 іншими засобами породжують інтелектуалізм, як одну з прикметних рис ідіостилю поета. Системний аналіз поетики оніма Є. Маланюка й розуміння мови як інтегральної науки є внеском до екстенсивних праць з літературної ономастики.

Перспективу подальшого дослідження вбачаємо в дослідженні стилістичної парадигми есеїстки Є. Маланюка, специфіки виражальних засобів різних мовних рівнів. 


\section{Література}

1. Калинкин В. Несколько замечаний к теории онимного пространства литературного произведения. Наукові записки. Вип. 37. Серія: Філологічні науки (мовознавство). Кіровоград: РВЦ КДПУ імені В. Винниченка, 2001. C. 167-169.

2. Маланюк С. Малоросійство. Книга спостережень. К.: Атіка, 1995. C. $219-233$.

3. Маланюк С. Вибрані твори [упоряд. текстів, передмова та примітки I. В. Немченка]. Харків : Ранок, 2009. 288 с.

4. Маланюк С. Земна Мадонна. Вибране [переднє слово, спогади, літературно-критичні праці, примітки, бібліографія та упорядкування М. Неврлого]. Братислава : Словацьке пед. вид-во, 1991. 470 с.

5. Маланюк $€$. Невичерпальність: поезії, статті [упоряд., передм. та приміт. Л. В. Куценка]. К.: Веселка, 1997. - 318 с.

6. Мельник Г. Ідіостиль збірки Свгена Маланюка «Земна Мадонна» $\mathrm{i}$ власні назви. Наукові записки. Вип. 1. Серія: Мовознавство. Тернопіль: Тернопільський нац. пед. ін.-т імені В. Гнатюка, 2008. C. $206-215$.

7. Немченко I.В. «І кожна рима - як свячений ніж...» (Із спостережень над поезіями С. Маланюка). URL: http: ekhsuir.kspu.edu > bitstream

8. Семенець О.О. Синергетика поетичного слова. Кіровоград: Імекс ЛТД, 2004. $338 \mathrm{c}$.

\section{References}

1. Kalinkin, V. (2001) Neskol'ko zamechanij k teorii onimnogo prostranstva literaturnogo proizvedeniya [A few remarks to the theory of onim space of literary work]. Naukovi zapysky. Vyp. 37. Kirovohrad: RVTs KDPU imeni V. Vynnychenka, 2001. S. 167-169.

2. Malaniuk, Ye. Malorosiistvo. Knyha sposterezhen [Observation book]. Kyiv: Atika, 1995. S. 219-233.

3. Malaniuk, Ye. Vybrani tvory [Selected Works]. Kharkiv: Ranok, 2009. 288 s.

4. Malaniuk, Ye. Zemna Madonna. Vybrane [Earthborn Madonna. Chosen]. Bratislava: Slovatske ped. vyd-vo, 1991. $470 \mathrm{~s}$.

5. Malaniuk, Ye. Nevycherpal'nist': poeziyi, statti [Inexhaustibility: poetry, articles]. Kyiv: Veselka, 1997. 318 s.

6. Melnyk, G. Idiostyl zbirky Yevhena Malaniuka «Zemna Madonna» i vlasni nazvy [Idiostyle of the collection of Yevhen Malanyuk «Earthborn Madonna» and proper names]. Naukovi zapysky. Vyp. 1. Ternopil: Ternopilskyi nats. ped. in-t imeni V. Hnatiuka, 2008. S. 206-215. 
7. Nemchenko, I.V. «I kozhna ryma - yak svyachenyj nizh...» (Iz sposterezhen` nad poeziyamy Ye. Malaniuka) [«And every rhyme - as like a holy knife...» (From supervisions of the poetry of Ye. Malaniuk)]. URL: http: ekhsuir.kspu. edu $>$ bitstream

8. Semenecz, O.O. Synergetyka poetychnogo slova [Synergetics of a poetic word]. Kirovohrad: Imeks LTD, 2004. 338 s.

\section{Анотація}

\section{I. М. Демешко. Антропонімікон у поезії Свгена Маланюка: семантико-стилістичний аспект}

У статті досліджено функційно-стилістичні особливості антропонімів у поезії С. Маланюка, описано їхню роль у вираженні основної ідеї, зокрема специфіку використання антропонімів у поезії Є. Маланюка, установлено їхню контекстуальну і функційну текстотвірну сутність, розкрито функційно-стилістичне навантаження антропонімів, використаних у творах, проаналізовано ситуації вживання моделей на тлі епохи й жанру. Досліджено вплив оніма на сприйняття образів читачем, визначено особливості ідіолекту поета крізь призму власних імен. Установлено, що використання антропонімів створює асоціативні зв'язки, що розширюють простір поезії, допомагають письменнику повніше висловити себе та встановити зв'язок з читачем.

На антропонімному матеріалі охарактеризовано індивідуальні авторські риси творення й використання імен, описано їхню роль у вираженні основної ідеї. Антропоніми, що є складовими елементами художнього тексту, репрезентують специфіку твору словесного мистецтва як системи. Твори Є. Маланюка $є$ цінним надбанням української культури, у якій оніми виступають іiі невід'ємними частинами.

Виявлено, що антропоніми формують і представляють у сукупності власний онімний простір у літературно-художньому творі і в усьому творчому доробку митця. Державницька історіософська концепція визначила організацію текстів С. Маланюка на всіх досліджуваних рівнях. Антропонімікон, використаний письменником, організовується в такі тематичні групи: митці, історичні діячі, міфологічні й біблійні персонажі, літературні персонажі, сучасники, авторські антропоніми. Досліджені одиниці становлять собою значущі національно-культурні компоненти і водночас виконують художньо-оцінювальну функцію в переважній більшості його текстів. Літературні антропоніми разом з іншими засобами породжують інтелектуалізм, як одну з прикметних рис індивідуального авторського почерку. Системний аналіз поетики оніма С. Маланюка й розуміння мови як інтегральної науки $\epsilon$ внеском до екстенсивних праць з літературної ономастики. 
Ключові слова: літературна ономастика, поетика, антропонімікон, історіософська концепція, національно-культурні компоненти.

\section{Аннотация \\ И. Н. Демешко. Антропонимикон в поэзии Е. Маланюка: семантико-стилистический аспект}

В статье исследованы функционально-стилистические особенности антропонимов в поэзии Е. Маланюка, описана их роль в выражении основной идеи, в частности специфика использования антропонимов в поэзии Е. Маланюка, установлена их контекстуальная и функциональная текстообразовательная сущность, раскрыта функционально-стилистическая нагрузка антропонимов, использованных в произведениях, проанализированы ситуации употребления моделей на фоне эпохи и жанра. Исследовано влияние онима на восприятие образов читателем, определены особенности идиолекта поэта сквозь призму собственных имен. Установлено, что использование антропонимов создает ассоциативные связи, расширяющие пространство поэзии, помогает писателю полнее выразить себя и установить связь с читателем.

На антропонимном материале охарактеризованы индивидуальные авторские черты творчества и использования имен, описана их роль в выражении основной идеи. Антропонимы, которые являются составными элементами художественного текста, представляют специфику произведения словесного искусства как системы. Произведения Е. Маланюка являются ценным достоянием украинской культуры, в которой онимы выступают ее неотъемлемыми частями.

Выявлено, что антропонимы формируют и представляют в совокупности собственное онимное пространство в литературно-художественном произведении и во всем творчестве художника. Государственная историософская концепция определила организацию текстов Е. Маланюка на всех исследуемых уровнях. Антропонимикон, использованный писателем, организуется в такие тематические группы: художники, исторические деятели, мифологические и библейские персонажи, литературные персонажи, современники, авторские антропонимы. Исследованные единицы представляют собой значимые национально-культурные компоненты и одновременно выполняют художественно-оценочную функцию в подавляющем большинстве его текстов. Литературные антропонимы вместе с другими средствами порождают интеллектуализм как одну из отличительных черт индивидуального авторского почерка. Системный анализ поэтики онимов Е. Маланюка и понимание языка как интегральной науки является вкладом в экстенсивные работы по литературной ономастике. 
Ключевые слова: литературная ономастика, поэтика, антропонимикон, историософская концепция, национально-культурные компоненты.

\section{Summary \\ I. M. Demeshko. Antroponymikon in the Poetry of Ye. Malanyuk's: Semantic and Stylistic Aspects}

Functional and stylistic peculiarities of the anthroponyms of Ye. Malaniuk's poetry are investigated, their role in expressing the basic idea, in particular the specificity of anthroponyms usage in Ye. Malaniuk's poetry is described, their contextual and functional text-forming essence is established, and functional and stylistic features are revealed, the situations of application of models against the background of the era and genre are analyzed. The influence of onims on the perception of images by the reader is investigated, the peculiarities of the poet's idiolect through the prism of proper names are determined. The use of anthroponyms has been found to create associative connections that extend the space of poetry, help the writer to express himself more fully and to connect with the reader.

The anthroponymic material describes individual author's features of name creation and use, describing their role in expressing the main idea. Anthroponyms, which are constituent elements of artistic text, represent the specificity of a work of verbal art as a system. Ye. Malaniuk's works are a valuable treasure of Ukrainian culture in which onims are its integral parts.

It is revealed that anthroponyms form and represent in a complex their own onim space in literary and artistic work and in all creative achievements of the artist. The state historiophysical concept defined the organization of Ye. Malaniuk's texts at all studied levels. The anthroponymicon used by the writer is organized into the following thematic groups: artists, historical figures, mythological and biblical characters, literary characters, contemporaries, and the author's anthroponyms. The studied units represent significant national and cultural components and at the same time fulfil an artistic and evaluative function in the vast majority of its texts. Literary anthroponyms, along with other means, generate intellectualism as one of the specific feature of individual author's handwriting. A systematic analysis of onim Ye. Malanyuk's poetics and understanding of the language as an integral science is a contribution to extensive works on the literary onomastics.

Key words: literary onomastics, poetics, anthroponymycon, historiosophical concept, national and cultural components. 
42 Наукові записки ХНПУ ім. Г.С. Сковороди. Літературознавство, 2019, вип. 3(93)

\section{Інформація про автора}

Демешко Інна Миколаӥвна - кандидат філологічних наук, доцент кафедри української мови Центральноукраїнського державного педагогічного університету імені Володимира Винниченка, вул. Шевченка, 1, Кропивницький, Україна, 25006; e-mail: demeshkoim@gmail.com; https:// orcid.org/ 0000-0002-2982-8675 